\title{
Endogenous Financial Structure and the Transmission of ECB Policy
}

\author{
Ivo J.M. Arnold \\ Nijenrode University \\ Casper G. de Vries* \\ Erasmus University Rotterdam, Tinbergen Institute \\ \& NIAS
}

There is a widely held view that existing differences in the capital and money market structures across EMU countries are an important matter of concern for the ECB, because they might hinder the uniform transmission of monetary policy actions. We argue that many aspects of financial structure are endogenous to the monetary policy regime in place. It is shown that capital market structures are heavily correlated with past inflation and inflation uncertainty. Since the EURO regime imposes a unified monetary policy, we suspect that the differences will wither. A single currency, a single money market rate and a uniform reserve requirement will rapidly harmonize the money markets. In sum, we predict that differential responses in the transmission of monetary policy actions through the money and capital markets are of minor concern for the ECB.

*Revision of our paper presented at the conference on 'Common Money, Uncommon Regions' organized by the ZEI, Bonn 24-25 July, 1998. Corresponding author: Casper G. de Vries, Tinbergen Institute, P.O. Box 1738, 3000 DR Rotterdam, The Netherlands; email addresses: arnold@nijenrode.nl and cdevries@few.eur.nl. We are grateful to our discussant Lars Svensson and the participants of the ZEI conference for their suggestions and to Harris Dellas, Juergen von Hagen, Heejoon Kang, Patrick Minford, Dave Smant and Christopher Waller for very helpful discussions. The second author benefitted from the hospitality of the NIAS where part of this paper was written. Version feb 23 


\section{Introduction}

As a legacy of the past, at the eve of European monetary union capital and money market structures still differ considerably across EMU countries. There is a widely held view among academics and policymakers that these differences are an important matter of concern for the ECB, as they might thwart a uniform transmission of monetary policy. Therefore, so the argument goes, the short and medium term real and financial market responses to monetary policy innovations will differ across the countries of the EMU.

In contrast to most studies in this area, we find that many characteristics of the financial structure in EMU economies are endogenous to the monetary policy regime in place. We distinguish between capital and money markets and investigate their endogenous response to monetary unification. It is shown that capital markets structures are strongly correlated with past inflation and inflation uncertainty. Since the EURO regime imposes a unified monetary policy resulting in nearly uniform inflation rates across the union, we suspect that the differences in the capital markets across EMU members will wither. In the money markets supply and demand will be harmonized due to introduction of a single currency, a single money market rate and a uniform reserve requirement. The money market responses to unification will take place instantaneously, while capital markets may take some more time. But then again, capital markets are forward looking and have long been discounting the effects of monetary unification, witness the convergence of swap rates. Hence, we predict that differential responses in the transmission of monetary policy actions will soon be of minor concern for the ECB. In fact, harmonization is probably propagated most rapidly if the ECB completely disregards the existing structural differences in the financial systems when it decides on the stance of monetary policy.

Almost all existing studies take the current financial structures as given, and proceed by analyzing how a uniform monetary policy can have differential (impact) effects. Several of these studies do recognize that the existing transmission mechanisms might change, but this possibility is usually not analyzed further. For the European money demand function several studies have tried to obtain an estimate by considering pre-union averages of the relevant variables. This may be the appropriate procedure to account for some of the endogenous changes due to monetary unification, but for some other changes it can be quite misleading, see below. Only a couple of studies have trotted the alternative route and suppose that money demand becomes more 
uniform. Concerning capital markets, quite a thorough documentation exists on the current differences and how these affect the transmission of monetary policy. Not much work exists on how these capital markets' structures will adapt to monetary union.

The present paper analyzes the endogenous response of the supply and demand for money, and investigates in a concise manner the structural changes that may arise in the capital markets. While we certainly do not claim to be able to cover all the endogenous effects, the paper does paint a broad picture of the evolution of the money and capital markets after unification. With the view of how financial markets will adapt to the new environment, we can infer whether or not the transmission of monetary policy actions by the ECB will give rise to differential responses across the EMU. In summary, we try to take the methodological point of the Lucas critique serious. For a dramatic institutional overhaul as monetary unification we believe that the endogenous response of agents is at the heart of the matter of transmission.

There is some irony involved in our story. One strand of the literature implicitly assumes that differential responses caused by different money and capital markets are a bad feature of the union, though the welfare losses are usually not explicated. The other strand of the literature actually considers the differential responses a virtue. The argument in the latter literature is that differences in the innovations in local money demand functions yield a more stable aggregate money demand function (through the law of large numbers effect). In the union monetary targeting would be facilitated by this apparent stability. These quite opposite welfare conclusions can be resolved by noting that the first strand of literature has the individual's welfare in mind, while the second literature concerns the welfare of the central banker in Frankfurt. Our story of endogenous response argues that a monetary union will eradicate the differences in the financial markets, producing a unisono transmission. Thus individuals in different parts of the union will benefit or suffer more or less equally from the unified monetary policy. For the central banker, this makes life more difficult since he cannot play on the law of large numbers. But in another way it makes his life easier since the effects of his policy actions will be similar across regions, and hence give less rise to nationalistic strive and jealousy. As a result, monetary policy may become truly European instead of remaining a compromise between the optimal policies for different countries. 


\section{Transmission Mechanisms}

Monetary policy innovations are first transmitted through the domestic and foreign financial markets and subsequently feed through commodity, service and labor markets, with important feedbacks to the financial markets. Hence, the transmission of monetary policy innovations may deviate between countries due to differences in the structure of financial markets, goods markets and labor markets. Currently there are important differences in all these markets across the union. We consider their relative importance for the transmission of monetary policy.

We first focus on the goods and labor markets. If the composition of the industrial and service sectors differs widely across regions, then the impact of monetary policy may be different. There is some evidence for this composition of output channel for the US. Carlino and DeFina (1997) show that there is a difference between the Great Lakes area and the other regions, due to the industrial specialization across US regions. We note, however, that this plays a much lesser role in the EU, where industry is much more homogeneously dispersed. Nevertheless, Carlino and DeFina (1998) find differences in transmission of monetary policy transmission between EU countries on the basis of the currently prevailing economic structures. A Bank of England study by Britton and Whitley (1997) uses a small stylized model based on Dornbusch's overshooting model to study the transmission in several EU countries. They find that exporting regions are more sensitive to monetary policy innovations due to the exchange rate effect. This sensitivity is likely to be even higher for the small trade focussed countries in the union. Labor market institutions vary considerably across the EU and imply different sensitivities to inflation surprises. At the end of the day, though, none of these differences is strong enough to cause: 'marked differences between the three economies in the response to output or inflation to a common change in policy interest rates', according to Britton and Whitley (1997). Dornbusch, Favero and Giavazzi (1998) review the evidence for differential responses derived from small and large econometric models. They argue that the lack of differences resulting from small models may be due to misspecification. Large models, on the other hand, do show differences but lack in comparibility across countries. An exception is the large model based study by Hughes Hallett and Warmedinger (1998) which does elicit some considerable differences based on comparable scenarios. By estimating a monetary policy reaction function and an output equation Dornbusch, Favero and Giavazzi 
(1998) also provide evidence for differential responses to monetary policy innovations on the basis of the industrial structure channel. Some evidence on this score for regions within Germany is presented in Hayo and Uhlenbrock (1998). In light of this latter evidence, an interesting question concerning the relevance of all these asymmetries is whether the differential effects between countries are larger or smaller than the variation between regions within a single country. To conclude, since the differences that exist in the goods and labor markets appear to have only minor consequences for the transmission of monetary policy and are unlikely to change rapidly, we will take these for granted and focus the analysis towards the financial markets where the endogenous response is likely to be of major importance right away. We recognize that over time and due to the unification specialization may increase and hence that the structure of the goods and labor markets may change, see e.g. Krugman (1993). But this process cannot be a matter of concern for monetary policy making in the EMU, since the unitary monetary policy making leaves no instruments for affecting this process, let alone the question of what influence would be desirable.

We therefore shift our attention towards the financial markets, where the endogenous response will be much more rapid. The differences in structure of the financial sectors across the EU are widely considered as major causes for the differential responses to monetary policy innovations in the EMU. Several studies have documented the considerable differences that exist between the countries of the EU in their financial structure. Dornbusch, Favero and Giavazzi (1998) for example perform policy experiments that document sizeable differences in speed and impact of monetary policy innovations for income and interest rates between EMU countries.

As is well known, the transmission in the financial markets works through the substitution and rebalancing of the whole array of assets. To simplify the spectrum of asset markets we only distinguish between a money market and a capital market. For capital markets Borio (1996), Kashyap and Stein (1997), Dornbusch, Favero and Giavazzi (1998), and Giovannetti and Marimon (1998) argue that differences in transmission arise due to asymmetries in the credit channel. These papers show that EU countries currently differ widely in the composition of private and public debt. This means that variables like the size of the debt as a ratio to GDP, the maturity of the debt, the collateral conditions and the amount of bank versus capital market financed investment induce variations in the speed by which interest rate hikes are passed on. 
While Borio (1996), Kashyap and Stein (1997), Britton and Whitley (1997) and Giovannetti and Marimon (1998) do recognize that : 'the EURO will change the way financial markets work, inducing corresponding changes in the monetary mechanism', to use the words of Dornbusch, Favero and Giavazzi (1998), this observation is not analyzed further in any of these studies. The next section tries to provide such an analysis for the capital market. We will argue that the existing differences in capital market structure have mainly come about due to differences in the monetary policy regimes that were in place. To show this, we first deduce how monetary policy regimes affect the structure of the credit. Specifically we relate the inflationary stances of past monetary policies to the maturity structure of debt. Once this relation is uncovered, we will have important evidence for the prediction that, in the words of Britton and Whitley (1997): 'As countries move to a single monetary policy... we might expect some convergence of behavior in both the extent of borrowing at long rates and the response of the yield curve to changes in policy rates'.

The money market is considered in even greater detail. We explicitly distinguish between supply and demand factors. Each side of the market contributes to existing differences in transmission. On the supply side not much work has been done except for the remark in Gros and Thygesen (1998, p.482) that average velocity will increase due to the imposition of uniform reserve requirements. Our quantitative analysis below also shows that the EU money multipliers will become more homogeneous due to the imposition of uniform reserve requirements.

The demand for money in the EMU has received considerably more attention in the literature. Absent EURO's, the larger part of this literature uses artificially constructed monetary aggregates in the estimation of a EURO money demand function. Notable papers in this line of research are Bekx and Tullio (1989), Kremers and Lane (1990), Artis, Bladen-Hovell and Zhang (1992), Läufer (1992), Monticelli and Strauss-Kahn (1993), Cassard, Lane and Masson (1994), Fase and Winder (1994), Artis (1996), Monticelli (1996), Tullio, De Souza and Giucca (1996), Fase and Winder (1997), Wesche (1997), La Cour and MacDonald (1997), Spencer (1997) and Fagan and Henry (1998). A survey of this line of research is provided by Browne, Fagan and Henry (1997). A consistent finding of these studies has been that a European-wide money demand function when judged by its residuals is much more stable than the constituent parts, offering support for the adoption of a monetary targeting framework by the ECB. 
Extrapolating from historical evidence is always a hazardous affair, even without a regime-shift. Faced with the EMU regime-shift, however, we must investigate whether endogenous changes can be adequately captured through an averaging of the variables. To this end, we need to know how the determinants of the demand for money will react to EMU. The point to note is that without a coordinated monetary policy individual country money demand may be rather unstable, while at same time the artificial EMU-wide money demand may appear to be much more stable owing to its construction as an average (through the law of large numbers effect). Once a single monetary policy is in place, however, money demand will become synchronized and hence the artificially constructed EURO money demand function may overestimate the stability of the actual demand for the EURO. This argument has been made by Arnold $(1994,1997)$. An economic analysis of the factors behind the synchronization due to endogenous response and a quantitative estimate of the expected increase in coherence is offered in Arnold and De Vries (1998) on the basis of the canonical monetary model of the exchange rate. The argument is concisely restated below with a back of the envelope quantitative evaluation. An interesting alternative approach to the endogenous change of the money demand equation is the study by Rother (1998). Rother uses a mean variance cash-in-advance framework with currency substitution and analyzes how the parameters and implied interest and wealth elasticities may change due to monetary unification. He finds that the demand for money becomes less sensitive to interest rate changes due to increased returns on holding cash. In both studies exogenously imposed changes in the means, variances and covariances of prices and exchange rates are used to back out the implied changes for the elasticities and endogenous variables.

At the ZEI conference our discussant raised another interesting explanation for the irrelevance of money market differences. Within the analysis of inflation targeting put forth by Svensson (1997) there is a direct causal chain running from lagged interest rates to inflation via lagged income. Svensson (1997) derives the important result that in this setup inflation forecast targeting, leading to a Taylor-type reaction function, is the optimal procedure if the central bank cares about inflation stabilization. Due to the direct link between the rate of interest and inflation in this framework, money demand disturbances do not interfere and monetary targeting would generally be inefficient. Hence, if the central bank uses its inflation forecast as the intermediate target, the stability or instability of the money demand relationship 
plays no role.

At the conceptual level the question is whether indeed the money market can be bypassed in linking inflation to "the" interest rate. For example, it can be noted that Svensson's (1997) model offers no monetary remedy for reviving the economy (escaping deflation) once the nominal interest rate has fallen to zero. The model embeds the liquidity trap. If, however, with a zero nominal rate agents would still substitute between assets once the central bank started buying securities at large, i.e. the professed monetarist remedy for Japan's current slump, then monetary policy is still potent and money demand innovations do play a role. Thus the causality in the system may be more complicated in nature than is suggested in the literature on inflation targeting. Specifically, if such a substitution mechanism is at work, one can no longer maintain that the interest rate that relates to aggregate demand is equal to the interest rate that equilibrates the money market. Hence the federal funds rate or its EMU equivalent has to be used to steer base money (or vice versa), and these quantities only indirectly via the money demand and supply equations affect the interest rates on the capital markets (which subsequently determine investment and aggregate demand). Within such a more complicated framework we nevertheless find that the unified monetary policy will eradicate existing differences in transmission.

Other aspects of reality, like the long and variable lags in transmission, complicate the optimal control view that often accompanies the motivation for inflation targeting. A particularly important problem in this respect is that inflation targeting requires inflation forecasts, which may induce multiplicity of equilibria due to the self-fulfilling prophecy nature of forecasting under this regime. Bernanke and Woodford (1997) therefore argue the necessity of structural modelling to be able to obtain rational forecasts that equal the target. This is, however, more easily said than done. It may prompt one to a less activist stance and to rely on simpler intermediate targets. ${ }^{1}$ So we agree that in implementing its monetary policy the ECB may just want to ignore possible differences in the impact of transmission for formulating the central bank policy actions, since these are not controllable anyway. ${ }^{2}$ But our motive for this ignorance is not so much that money market disturbances do not play a role, but rather that they will be harmonized through the unifica-

\footnotetext{
${ }^{1}$ Over a sufficiently long planning horizon, though, there is little to choose between inflation targeting and, say, monetary targeting.

${ }^{2}$ This observation applies to most targeting procedures.
} 
tion process and cannot be separately controlled. Thus monetary targetting may be problematic untill the dust has settled.

To summarize, the changes in the short and medium term that can be expected to affect the transmission mechanism are predominantly due to changes in the financial markets. We distinguish between capital and money markets. For each market, we analyze the consequences of monetary unification by taking into account that existing structures will be altered by the very process of unification. This is different from the approach by most other studies in the area which extrapolate on the basis of existing structures.

\section{Capital Markets}

In this section we analyze how the EMU capital market structure will be affected by monetary unification. We take a rather pragmatic approach. We will identify the capital market structure by means of a single variable, the maturity structure of debt. The single variable approach cannot do full justice to the complexity of capital markets. Moreover, the maturity structure itself can be measured in different ways. Nevertheless, it is argued below in greater detail that several of the important features of capital markets correspond with a particular maturity structure. On the basis of these arguments the maturity is used as the empirical measure of the capital market structure. We subsequently relate the maturity structure to inflation and inflation uncertainty. Bearing in mind the limited amount of data we have, we uncover quite a strong inverse relation between either of the two explanatory variables and the maturity measure. Given this inverse relation, our prediction is that the unified monetary policy, which generates a nearly homogenous rate of inflation in the EMU, will bring about a unified maturity and hence a single capital market structure. Before we make this string of arguments, we first ask the question why there exist any nominal debt contracts at all, i.e. why there is debt with a non-zero maturity.

\subsection{Why nominal debt?}

If all debt were indexed there would not be much of a maturity structure. In other words, there would not be a relation between inflation and maturity. Why is it that a major portion of debt is contracted in nominal terms, thus permitting a relation between maturity of the contract and inflation? We 
present an eclectic overview of the arguments.

A first explanation is that it may be difficult to agree on the appropriate inflation index. The index is likely to be different for different agents, see e.g. Minford and Nowell (1998) who use this argument to explain nominal wage contracts. A related argument made by Magill and Quinzii (1996, p.480-481) is that a price index also picks up relative price changes. Typically, one does not want to compensate for real shocks, recall the Dutch disease. Thus if one indexes the vice of relative price risk is substituted for the vice of inflation risk. In a low inflation environment the former risk may be the more serious one.

The private sector, as far as the larger company corporate sector is concerned, has three main categories of instruments for financing their business, i.e. equity, bonds and intermediated loans. A specific firm is knowledgable about its own (product price) risk, to which it can tailor its finances. But the firm does not have a comparative advantage in managing the general price level risk. For this reason the firm and investor may have a preference for debt contracts in nominal terms. Debt is often seen as a disciplinary tool that takes away the managerial slack induced by equity finance (in many countries it also provides a tax advantage to the shareholders). If indexed, debt also makes the manager worry about inflation risk, and this obfuscates the goal of improving the managerial incentives. Moreover, if nominal debt is issued, it makes this mode of financing directly comparable to floating stock (the general price level risk premium does not have to be filtered out first).

The bondholders and stockholders of the respective securities assume the firm risk and the macro risk of unanticipated changes in the general price level. From the point of view of an investor, the firm risk is largely carried by equity. Bonds on the other hand are mainly subject to price level risk (junk bonds and warrants are derivative products that combine the two risks). Hence debt in nominal terms may be preferred by the investor, because it enables him to combine the two sorts of risks optimally in a simple manner. Also note that a portfolio comprised of longer and shorter maturities at least attains a partial hedge against inflation through the possibility of rolling over the short term debt instruments.

For the government and for regulated industries like utilities floating equity is not an option since the profits of the sovereign, who has the power to tax, are not a well defined concept (voting rights substitute for shareholder influence). For the government debt is the means of intertemporal transfer of wealth. One may ask why governments are able to sell nominal debt at 
all since they (often) have the power to inflate. But then again, governments also have the power to tax, and can appropriate real debt. Apart from the objective of intertemporal budget transfers, nominal government debt may also be issued to attain some risk sharing of macro policies with the investment community. Nominal debt, like cash, provides an insurance against the business cycle due to its anticyclical properties insofar the cycle is induced by real shocks. Investors therefore have demand for nominal bonds and cash to offset the procyclical risk of equity investment. Moreover, in case of emergencies like war, the inflation tax may be the most expedient instrument available to raise revenues quickly.

Governments have issued indexed debt. The way this is done most often is through issuing debt denominated in a foreign currency. With a few exceptions, indexed debt is mostly floated by inflation prone governments. The macro literature, though, does not offer an unambiguous argument for the merits of indexed issues, see the discussion by Persson, Persson and Svensson (1987), Calvo and Obstfeld (1990), Missale and Blanchard (1994) and Campbell and Shiller (1996). These articles discuss the virtue of indexed debt as a disciplinary device. Another argument pro indexing is that indexed debt fills a gap in the spectrum of the yield curve.

To conclude, there is indexed and non-indexed debt. Nominal debt exists for various risk related arguments. In case inflation risk is the dominant risk factor, direct indexation is likely to occur. If other risk factors dominate nominal claims are issued. In that case partial indexation can be achieved in a indirect manner through the maturity structure of the debt. We now turn to investigate the determinants of the maturity structure, and then come back to the issue of the relation between the maturity structure and the inflationary environment.

\subsection{Maturity structure}

Studies by the BIS on the structure of credit and balance sheets in the EU countries by e.g. Borio (1996) and Kneeshaw (1995) report large differences in the share of long versus short term borrowing by the private and public sector. We consider five explanations for the maturity structure of nominal debt. The first four arguments use financial market incompleteness and involve typical moral hazard and adverse selection situations in an environment of asymmetric information. 
1. Public and Private Moral Hazard, Maturity as a Monitoring Device. In the private sector debt is used as a disciplinary device for the management by the shareholders. But in times of financial distress debt may have an adverse affect since it tempts the manager to take on excessive risk (if the type of projects chosen by the manager are not contractual). To secure against such moral hazard, the maturity can be shortened. This reduces the sensitivity of the debt to high variance projects, and thereby lowers the incentive of the manager to switch to running high risk projects, see Barnea, Haugen and Senbet (1980). On the public side a similar argument exists, especially if the government controls the money presses. Missale and Blanchard (1994) make the argument that the higher the level of the debt and the longer its maturity is, the higher is the temptation to inflate the debt away. To counter this incentive, the maturity can be shortened as the amount of debt increases. We note that in the EMU the money press is no longer under direct control of individual governments.

2. Credit Rationing. Adverse selection in the credit market occurs when high interest rates invite disproportionately bad risks, see Stiglitz and Weiss (1981). This may cause banks to limit the amount of debt on their books. Bester (1985) argued that this problem of endogenous credit rationing may be less severe than it appears if the debtor can provide collateral. Where governments may not be able or willing to provide collateral, the maturity structure provides an alternative. A shorter maturity provides less temptations to the (sovereign) debtor and more security to the creditor. Of course commercial banks also often limit agent risk by limiting the maturity, i.e. they cap the price level risk by recurrently adjusting the interest rates and limit the credit risk by requiring collateral.

3. Regulation and Expenditure Discretion. This explanation hinges on the amount of firm and government discretion, i.e. the impossibility to contract via the political process on future behavior. It has been observed that regulated firms have more long term debt, see Barclay and Smith (1995). As Barclay and Smith explain: 'Managers of regulated firms have less discretion over future investment decisions than managers of unregulated firms'. Similarly, we expect governments that operate under a tighter set of budgetary rules and other disciplining devices to 
exhibit less discretion on the expenditure side, and to be able to borrow longer; Lemmen (1998) provides some evidence. Thus regulation may be seen as an alternative solution to the moral hazard problem, and hence it acts as a substitute for maturity. From this point of view the Maastricht treaty, which has taken central bank policy outside the realm of direct influence of individual governments, and the stability pact, insofar as it carries any credibility, should lengthen the maturity of state debt in the various EU countries. So institutions may act as substitutes for maturity caps.

4. Risk Aversion and Debt. Consider a high and a low risk project in an incomplete markets setting. The high risk project has one or several nodes ending in the red, whereas this is not the case for the low risk project. The riskiness of the high risk project can be lessened if an adverse development could be stopped early on by withdrawing finances. Such a reduction in riskiness through early stopping, as in the case of credit rationing, improves the terms at which the loans will be made. Because more investors are now willing to participate in the high risk project instead of sticking to the low risk project. The improved terms of borrowing may also improve the prospects for the project. In such a case the adverse selection problem is that society invests in too few high risk projects if the maturity structure is too long. Junk bonds and venture capital do have value.

5. Tax Regime. The most important factor in explaining the amount of leverage was provided by Miller and Modigliani (1958) through the tax shield when corporate and personal income tax rates differ. With a tax advantage due to the deductability of interest payments, shareholders' wealth is increased if the firm is partly debt financed. Since most debt has a finite maturity, whereas equity has unlimited maturity, the tax regime is an important determinant of the maturity structure of the assets issued by the private sector.

To conclude, many of the structural features of capital markets are determinants of the maturity structure of private and public debt. Some of these features are a direct product of the budgetary and monetary policies of the public authorities, some other features are intrinsic to the nature of the national industries. Below the partial relation between monetary policy and 
the capital market structure is exploited further for the issue of monetary union and the transmission of monetary policy.

\subsection{Inflation and maturity}

In the foregoing subsection we discussed the determinants of the maturity structure of the nominal debt that hinge on asymmetric information, incomplete contracts and the tax regime. Some, but not all, of these determinants are intimately connected to the inflationary stance of the government policies. In the first subsection we discussed why there exists non-indexed debt at all. We argued that the usage of non-indexed debt hinges on the trade-off between the risk of inflation versus other risks such as relative price movements. It follows from these arguments that indexing in one form or another, e.g. by shortening the maturity or by writing indexed contracts directly, will receive more attention as the (risk of) inflation increases.

Specifically, from the two previous subsections we identify the following links between inflation and maturity. The preference for nominal debt contracts vis-a-vis indexed contracts decreases, and hence the maturity is shortened, if inflation and inflation uncertainty increase. The public moral hazard for inflating away the deficit can be contained through a reduction in the maturity, and governments may have an incentive to signal their credibility in this respect. Private agents when buying foreign government debt secure against adverse selection of high risk inflation prone countries through offering these countries short term loans denominated in foreign currency. Both loan qualities effectively reduce the maturity when measured in the home currency. Constitutional safeguards against monetization of public debt lengthen the maturity structure of public debt. Popular measures for such safeguards are the fiscal rule index as an indicator for budgetary stringency, see Lemmen (1998), and the central bank independence measure as an indicator for the scope of the inflation tax. It is well known that the independence measure correlates with the level of inflation, see Cukierman (1992), Eijffinger and De Haan (1996) and Eijffinger, Schaling and Hoeberichts (1998). In contrast the private moral hazard argument for limited maturity debt, the private adverse selection argument for collateral and the constraints on regulated industries enabling long term debt financing, bear little or no relation to the inflationary environment.

In summary, we have the following conclusions. There are two sources which determine the capital market structure in an economy: (i) The infla- 
tionary regime, and (ii) Other primarily micro based factors. A summary measure of the capital market structure is the average maturity in an economy. The latter catch-all is stark. For a given average maturity the capital markets structure is not unambiguously fixed since some of the determinants are substitutes. ${ }^{3}$ Equating the two concepts provides a first cut at the empirical issue. Our empirical methodology is now as follows.

In the empirical subsection we relate the average maturity of debt in an economy to its inflationary environment. Once this relation is established, we use it to predict the capital market structure under EMU conditional on a specific inflationary stance of the ECB (which the reader can choose for himself, since the paper is not about predicting the inflation level that will materialize). We use no measure for the other determinants of the maturity. This partial correlation approach works if: (i) The relation between inflation and maturity is an important one, or, in other words, a regression yields a high partial correlation coefficient $\rho$; and (ii) the other determinants will not change too much due to the monetary unification so as to upset the partial relation. Note that insofar the changes in these other determinants are colinear with the inflation variable, the omitted variable bias still produces the right answer. Thus we assume from the outset that the other determinants, like the real risks inherent to certain projects, are unperturbed by the unification process or correlate with the inflationary regime. We also suspect that in the past few decades the cross-country variation in private sector determinants of maturity and capital market structure in the EU have been dominated by the (strong) cross-country variation in the inflationary environments.

We use the mean inflation rate and the variance of inflation to represent the inflationary environment. These measures are highly correlated. Friedman (1977) and Ball (1992) argue that the level of inflation explains the variance of inflation, while Cukierman and Meltzer (1986) argue the converse. Arnold and Den Hertog (1995), Groeneveld (1998, Chapter 6) and Grier and Perry (1998) uncover the empirical relationships. Since we are only concerned with per country averages of the variables over longer spans of time we are not interested in the causality issue; we only notice the high intercorrelation that results one way or another. For some of the determinants of maturity the inflation level and for some other determinants inflation

\footnotetext{
${ }^{3}$ It is thus a one way street: A particular capital market structure implies an average maturity. But the same maturity may be associated with different capital market structures.
} 
uncertainty is the natural instrumental variable. Due to the multicollinearity problem, however, we will only use one explanatory variable at a time.

\subsection{Empirical Evidence}

From Borio (1996), Kneeshaw (1995) and the EMI Convergence Report (1998), we collected data on the maturity structure of financial instruments. Average inflation $\mu_{\pi}$ and inflation uncertainty measured as the standard deviation of inflation $\sigma_{\pi}$ are constructed from annual country data over the years 1975-1995. We considered the following 20 countries: All 15 EU countries, Australia, Canada, Japan, Switzerland and the United States. The table below reports the correlation coefficient $\rho$, t-statistics ts (on $H_{0}: \rho=0$ ) and the $R^{2}$ for partial correlations of the maturity variable with either average inflation or inflation uncertainty.

Table (1) shows that even for the limited amount of financial structure data the maturity is distinctly inversely related to the level of inflation and inflation uncertainty. The inflationary environment variables are also important quantitatively, since at least $50 \%$ of the variance of the maturity is explained by these variables. Both inflation and inflation uncertainty yield very similar correlation patterns with the financial structure variables. As was explained above, this stems from the fact that inflation and inflation uncertainty are heavily correlated. In our data the correlation coefficient between inflation and inflation uncertainty is 0.88 . The results, in a way, turn the evidence on the differences in the financial structures and monetary policy impact effects upside down. We mentioned several studies which concluded that monetary policy innovations are transmitted differently across EMU countries due to differences in the financial sector, and suggest that this may also be the case under the EMU, at least for some time to come. In this view the financial structure, i.e. maturity, is taken as exogenously given. We find that the financial structure, which reflects the differences in monetary policy regimes, varies with the inflation differences in a predictable way. The inverse relation makes economic sense. Moreover, inflation has quite some explanatory power. We also noted that there are other determinants of the maturity, and hence the less than perfect correlations. But, as explained above, for the issue of unification these variables are unlikely to be important. If so, we can expect that the EMU will bring about a homogenous financial structure, because there will just be a single monetary policy and a single rate of inflation. Already for quite some time capital markets 
Table 1: Inflation, Uncertainty and Maturity

\begin{tabular}{|c|c|c|c|c|c|c|c|}
\hline Maturity Measure & $\#$ & $\begin{array}{l}\mu_{\pi} \\
\rho\end{array}$ & ts & $R^{2}$ & $\begin{array}{l}\sigma_{\pi} \\
\rho\end{array}$ & ts & $R^{2}$ \\
\hline \multicolumn{8}{|l|}{ Private Sector } \\
\hline \multirow{2}{*}{$\begin{array}{l}\text { \% short term } \\
\text { total credit }(1983) \\
\text { total credit }(1993)\end{array}$} & $\begin{array}{l}12 \\
14\end{array}$ & $\begin{array}{l}0.79 \\
0.78\end{array}$ & $\begin{array}{l}4.02 \\
4.27\end{array}$ & $\begin{array}{l}0.62 \\
060\end{array}$ & $\begin{array}{l}0.81 \\
070\end{array}$ & $\begin{array}{l}4.40 \\
3.44\end{array}$ & $\begin{array}{l}0.66 \\
0.50\end{array}$ \\
\hline & 14 & 0.78 & 4.27 & 0.60 & 0.70 & 3.44 & \\
\hline loans (1983) & 12 & 0.78 & 3.93 & 0.61 & 0.81 & 4.40 & 0.66 \\
\hline loans (1993) & 14 & 0.79 & 4.42 & 0.62 & 0.76 & 4.09 & 0.58 \\
\hline consumer loans (1993) & 10 & 0.67 & 2.60 & 0.45 & 0.43 & 1.34 & 0.18 \\
\hline business loans (1993) & 10 & 0.80 & 3.77 & 0.64 & 0.81 & 3.96 & 0.66 \\
\hline mortgages (year n.a.) & 14 & 0.52 & 2.10 & 0.27 & 0.43 & 1.66 & 0.18 \\
\hline \multicolumn{8}{|l|}{ Non-Financial Sector } \\
\hline \multicolumn{8}{|l|}{$\%$ long term debt } \\
\hline to GDP $(1993)$ & 12 & -0.70 & -3.21 & 0.49 & -0.68 & -2.91 & 0.46 \\
\hline to total debt + equity $(1993)$ & 10 & -0.60 & -2.14 & 0.36 & -0.63 & -2.35 & 0.40 \\
\hline \multicolumn{8}{|l|}{ Public Sector } \\
\hline \multicolumn{8}{|l|}{$\%$ short term debt } \\
\hline 1991 & 13 & 0.45 & 1.68 & 0.20 & 0.30 & 1.06 & 0.09 \\
\hline 1996 & 15 & 0.55 & 2.40 & 0.30 & 0.51 & 2.15 & 0.26 \\
\hline \multicolumn{8}{|c|}{$\begin{array}{l}\text { Private sector data are from Tables 5-8 in Borio (1996). The non-financial sector data } \\
\text { are from Table } 5 \text { in Kneeshaw (1995). The public sector data are derived from the EMI } \\
\text { convergence report (1998, Tables 5). Inflation data } \pi \text { are annual data over the period } \\
1975-1995 \text { from several issues of the IMF IFS tables. The number of observations is } \\
\text { reported under } \#, \rho \text { is the correlation coefficient, } t s \text { stands for the t-statistic and } R^{2} \text { is } \\
\text { the coefficient of determination. }\end{array}$} \\
\hline
\end{tabular}


have anticipated on this unitary regime. This is clear from the convergence of interest rates which long ante dates the start of the union. As a result, the concern for sharp differential responses to monetary policy innovations across EMU regions due to capital market differences is, in our view, of minor importance, even at the start of the EMU in 1999. Of course some discrepancies between local capital markets will still be present after the start of EMU. One only has to think of the markets for pensions or mortgages. But further integration is probably best stimulated if the ECB ignores these differences in setting monetary policy and joins the European Commission in actively championing the cause for financial integration and promoting the elimination of the remaining barrieres between Europe's financial sectors.

One always has to be careful in drawing causal statements from a correlation exercise like this. One can imagine the reversed causality that a highly indexed society lends itself more easily to inflationary policies. Nevertheless, we believe on the basis of the theoretical arguments set out before, that the financial structure responds to the monetary policy stance of the authorities rather than the converse. Another potential objection to our inference runs as follows. Due to the existing differences in transmission, the rate of inflation will differ across countries. Hence, the presumption of a single inflation rate that generates a unitary capital market structure is wrong. Admittedly, this is a more serious methodological point. But we believe that large differences in inflation cannot arise due to arbitrage; c.f. the case of the USA. The next section provides evidence on how increased monetary unification eliminates divergences in inflation patterns.

As we noted before, the paper is not about predicting the rate of inflation that will materialize. In principle our result holds regardless the specific inflationary stance of the ECB. It is somewhat tempting to conclude, however, that since monetary policy will be outside the realm of the fiscal authorities, the temptations to inflation may be small and we can expect the average maturity to increase. This would change if the finance ministers organized in ECOFIN would gain more influence. It is still too early to foresee whether the Maastricht treaty and the stability pact indeed provide enough guarantees and safeguards against inflationary policies. 


\section{Money Markets}

A truly unified European monetary policy exists as soon as monetary impulses from the ECB are swiftly and uniformly transmitted throughout the currency union, according to Giannini and Monticelli (1997). This will probably be first achieved in the money market. For money markets, the switch to EMU entails a regime-shift which is more sudden and sweeping than for capital markets. To assess the effects of the unification of Europe's money markets on the behavior of monetary aggregates, we explicitly distinguish between money supply and money demand factors, starting with the supply side.

\subsection{Money supply}

From January 1, 1999, the new euro money supply will be steered from the ECB in Frankfurt, using monetary operating procedures which are identical for all EMU members. Any cross-country differences in the money supply process caused by hirtherto existing differences in e.g. the reserve requirements system will be ironed out. Other differences like those caused by national statistical idiosyncracies will be eliminated by the adoption of a uniform reporting framework for banking statistics in the EMU area. This does not imply that the money multiplier will be exactly the same in all EMU countries: Local payments habits may still result in different cash-deposits ratios and thus different money multipliers. Nevertheless, the uniform reserve requirements will have a sizeable and immediate effect. Table (2) below shows the components of the money multiplier for 14 European states during 1995. Recall that the money multiplier can be written as

$$
\frac{1+\text { Cash/Deposits }}{\text { Cash/Deposits+Reserves/Deposits }} \text {. }
$$

European cash-deposits ratios still differ widely, ranging from a high of $21 \%$ in financially less sophisticated Greece to a low of $3 \%$ in the United Kingdom. The variation in reserves-deposits ratios is even larger. This reflects the diversity in reserve requirements systems existing in Europe until the start of the union. As a result, the money multipliers range from 3 in Greece to almost 26 in the United Kingdom, see Table (2) column three.

The final two columns in Table (2) show the effect on the multipliers if we impose a uniform reserves-deposits ratio on all countries under two alterna- 
Table 2: Money Multiplier Synchronisation

\begin{tabular}{|c|c|c|c|c|c|}
\hline Country & $\frac{\text { Cash }}{\text { Deposits }}$ & $\frac{\overline{\text { Reserves }^{2}}}{\text { Deposits }^{2}}$ & Multiplier ${ }^{3}$ & $\begin{array}{l}\text { Adjusted } \\
\text { multiplier }^{4}\end{array}$ & $\begin{array}{l}\text { Adjusted } \\
\text { multiplier }^{5}\end{array}$ \\
\hline Austria & $7.08 \%$ & $3.44 \%$ & 10.17 & 8.10 & 11.79 \\
\hline Belgium & $7.03 \%$ & $0.75 \%$ & 13.76 & 8.13 & 11.85 \\
\hline Denmark & $5.62 \%$ & $7.55 \%$ & 8.02 & 8.98 & 13.86 \\
\hline Finland & $4.04 \%$ & $14.96 \%$ & 5.48 & 10.22 & 17.23 \\
\hline France & $5.23 \%$ & $1.03 \%$ & 16.81 & 9.25 & 14.56 \\
\hline Germany & $12.13 \%$ & $3.91 \%$ & 6.99 & 6.14 & 7.94 \\
\hline Greece & $20.71 \%$ & $13.73 \%$ & 3.06 & 4.49 & 5.31 \\
\hline Ireland & $10.18 \%$ & $7.57 \%$ & 6.21 & 6.75 & 9.05 \\
\hline Italy & $9.83 \%$ & $7.95 \%$ & 6.18 & 6.87 & 9.28 \\
\hline Netherlands & $7.67 \%$ & $2.85 \%$ & 10.23 & 7.80 & 11.14 \\
\hline Portugal & $7.19 \%$ & $3.22 \%$ & 10.30 & 8.04 & 11.67 \\
\hline Spain & $15.39 \%$ & $2.86 \%$ & 6.32 & 5.36 & 6.64 \\
\hline Sweden & $10.18 \%$ & $15.17 \%$ & 4.35 & 6.75 & 9.05 \\
\hline UK & $2.99 \%$ & $1.01 \%$ & 25.73 & 11.27 & 20.63 \\
\hline $\begin{array}{l}\text { standard } \\
\text { deviation }\end{array}$ & & & 5.96 & 1.85 & 4.14 \\
\hline
\end{tabular}

$\overline{\overline{1} \text { Cash is the Currency outside deposit money banks (line 14a IFS). Deposits are Money }}$ plus Quasi-money (lines 34 and 35 IFS) minus Cash (all data are for 1995).

${ }^{2}$ Reserves are equal to Reserve money (line 14 IFS) minus Cash.

${ }^{3}$ Multiplier $=(1+$ Cash/Deposits $) /($ Cash/Deposits + Reserves/Deposits $)$.

${ }^{4}$ The adjusted multiplier is calculated using national Cash/Deposits ratios and the average of the 1995 European Reserves/Deposits ratios (equalling 6.14\%).

${ }^{5}$ The adjusted multiplier is calculated using national Cash/Deposits ratios and the minimum required Reserves/Deposits ratio (equalling 2.00\%). 
tive scenarios. The exercise is based on the harmonization of the minimum reserve requirements system effective January 1999 and the presumption that European banks have uniform preferences to hold excess reserves. Under the first scenario the Reserves/Deposit ratio is set equal to the 1995 average. The second scenario uses the extreme case whereby the Reserves/Deposit ratio is set equal to its minimum of $2 \%$. The cross-sectional variation in the money multipliers is instantaneously reduced by at least $30 \%$ and quite likely by much more, see the standard deviations at the bottom of the table. Another supply factor that will contribute to this harmonization is the start of the TARGET-real time gross settlement system that will link once segmented money markets. We may therefore expect that the endogenous response in the money supply process will result in an instantaneous increased comovement of money supplies across the EMU area. How will this homogeneous supply filter to the demand side?

\subsection{Money demand}

Barring a few notable exceptions, existing studies on the demand for EURO's mostly presume that there will be large differences across the EMU members in the impact of monetary policy innovations on their money markets. A number of these studies even rely on the necessity of these country differential responses in order to obtain an aggregate demand function that is more stable than the individual country demand functions. Here we like to argue, though, that the larger part of the current differences in response will quickly be eliminated due to the endogeneity of the demand factors.

In particular, we would like to argue that studies which use averages of past variables to estimate the average demand for EURO's yield a distorted view of how the aggregate demand for EURO function is going to behave. There are two sorts of integration effects under which averaging is appropriate. First, insofar as national shocks to e.g. payments habits, labor markets and fiscal policy remain independent, the Law of Large Numbers bestows its virtues on the aggregate demand for money. The question is how important these independent movements are vis-a-vis the (new) EURO aggregate shocks, such as interest rate changes, which come along with the unified policy. Other examples of unification effects which synchronize rather than distribute are the international trade and reserve demand for EURO's, and the business cycle synchronization that is induced by the fixing of exchange rates, see Artis and Zhang (1996), Fatás (1997) and Artis, Kontolemis and 
Osborn (1997) for evidence on this for the ERM period. Second, the early literature on European money demand explained the apparent stability of the average demand for money in Europe from the existence of currency substitution between the European currencies. Due to the unification currency substitution would disappear, and hence local demand for EURO's would become more stable as well. This explanation, though, conflicts with the repeated failure to find any direct evidence of currency substitution in the EU, see Bundesbank (1995) for a survey. A more trivial explanation, offered by Arnold (1994), holds that the superior performance of the European aggregate is the result of national shocks that average out. This can only persist in the (unlikely) event that all shocks to money demand determinants continue to operate independently on a national level post-EMU. This, however, goes against the basic economic intuition that inside a monetary union, monetary developments to a large extent run in parallel.

Evidence confirming this intuition is provided in Table (3), which is inspired by De Grauwe (1996). Table (3) compares long-term patterns in the price level and the velocity of demand deposits for two datasets: data from regions within monetary unions, i.e. Germany and the United States, and data from European countries. All series are indexed to 100 in the base year. The final column shows the cross-sectional coefficient of variation of the index in the final year of the sample. ${ }^{4}$ The measure shows the extent to which the times-series have fanned out over the sample period. The higher this measure, the more the time-series have diverged during the sample period. Its minimum value is zero, which occurs when all time-series in the cross-section end up having the same value. The price data show that German regional price indices have stayed close together over the whole sample period, in sharp contrast with the European price indices (EUR12): Just compare the values 0.03 and 1.05. For a smaller group of 'core' EMS countries (EUR5), however, the outcome resembles the German picture more closely, especially if we look at the 1983-1995 subperiod. The bottom half of Table (3) shows the results for the velocity of demand deposits. The velocity data also point to a wide divergence in the time-series of the European cross-section in comparison to the German and U.S. cross-sections. Again, we can observe a notable distinction between the large European group (EUR12) and the core

\footnotetext{
${ }^{4} \mathrm{We}$ use the coefficient of variation since it is insensitive to differences in scale, whereas the standard deviation is not. The disadvantage is that the mean must not become too small; but this is not a problem for the current data.
} 
Table 3: Diverging Trends in Prices and Velocity

\begin{tabular}{lccc}
\hline \hline & $\begin{array}{c}\text { base year } \\
\text { (index=100) }\end{array}$ & end year & $\begin{array}{c}\text { cross-sectional coefficient of } \\
\text { variation of index in end year }\end{array}$ \\
PRICES & & & \\
\hline European nations ${ }^{1}$ & & & 1.05 \\
EUR12 & 1974 & 1995 & 0.30 \\
EUR5 & 1974 & 1995 & 0.09 \\
EUR5 & 1983 & 1995 & 0.03 \\
German regions ${ }^{2}$ & & & 0.02 \\
GE & 1974 & 1995 & \\
GE & 1983 & 1995 & 0.47 \\
VELOCITIES OF DEM AND DEPOSITS & 0.17 \\
\hline European nations & & & 0.28 \\
EUR12 & 1974 & 1995 & 0.14 \\
EUR5 & 1974 & 1995 & 0.09 \\
EUR5 & 1983 & 1995 & \\
U.S. regions & & & \\
US & 1967 & 1988 & \\
German regions & 1989 & 1996 & \\
GE & & & \\
\hline \hline
\end{tabular}

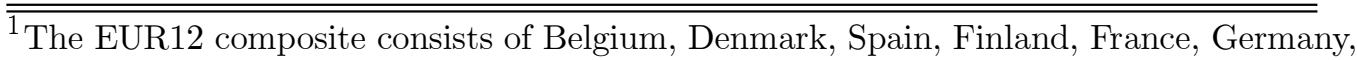
Greece, Ireland, Italy, Netherlands, Austria and Portugal; the EUR5 comprises Belgium, France, Germany, Netherlands, Austria. Data on prices are from European Economy; velocities of demand deposits are based on IFS data.

${ }^{2}$ Price and demand deposit data for 10 (West)-German regions were kindly provided by the Bundesbank.

${ }^{3}$ Data on the velocities of demand deposits for 8 U.S. regions were kindly provided by Peter Ireland. The data are only available up to 1988; also Arnold (1997). 
group (EUR5).

\subsection{Money demand coherence interpreted}

An economic explanation for the distinctly similar velocity and price movements in a union as we see in Table (3), can be obtained by asking how the disparity arises between countries that operate independent monetary policies. In such a world, and without capital market restrictions, exchange rates equilibrate the demand and supply for the different currencies. The exchange rate movements to a large extend carry the burden of the idiosyncratic national nominal shocks. But once a single monetary policy is in place and exchange rates are irrevocably fixed, innovations in monetary aggregates have become very similar across the union, since the equilibrating force for substantiating differences has been thrown out of the window. A standard monetary exchange rate model can be used to give quantitative content to the amount of increase in coherence that can be expected following unification.

Take the relative form of the PPP hypothesis and allow for arbitrage imperfections through $\varepsilon$ :

$$
\Delta s=\left(\Delta p-\Delta p^{*}\right)+\varepsilon,
$$

where $\Delta s$ is the change in the logarithmic exchange rate, and $\Delta p$ and $\Delta p^{*}$ are respectively the domestic and foreign logarithmic changes in the price indices. The relation (1) can also be interpreted as a relative pricing kernel, in which case $\varepsilon$ embodies the intertemporal marginal rates of substitution, see Backus, Foresi and Telmer (1996) and Arnold and De Vries (1998). The relative country version of the quantity equation $M V=P Y$ in logarithmic first differences reads

$$
\Delta p-\Delta p^{*}=\left(\Delta m-\Delta m^{*}\right)+\left(\Delta v-\Delta v^{*}\right)-\left(\Delta y-\Delta y^{*}\right) .
$$

Denote a relative country variable as $\Delta \widetilde{x}=\Delta x-\Delta x^{*}$. Combine (1) and (2) to obtain an expression for the forex returns under a regime of free float

$$
\Delta s=\Delta \widetilde{m}-\Delta \widetilde{y}+\Delta \widetilde{v}+\varepsilon .
$$

In order to fix exchange rates, monetary policy must be made subservient to this goal. Note that one only needs to fix the monetary policy of member countries relative to one another, not the absolute level. To reflect this switch in endogenous and exogenous variables, rearrange (3) to obtain

$$
\Delta \widetilde{m}=\Delta s+\Delta \widetilde{y}-\Delta \widetilde{v}-\varepsilon .
$$


Equations (3) and (4) are the tools for analyzing the endogenous response of relative country money supply growth following monetary unification. Without unification we have from (4) that

$$
\begin{aligned}
V \Delta \widetilde{m}= & V \Delta s+V \Delta \widetilde{y}+V[\Delta \widetilde{v}] \\
& +2 C[\Delta s, \Delta \widetilde{y}]-2 C[\Delta s, \Delta \widetilde{v}] \\
& -2 C[\Delta \widetilde{y}, \Delta \widetilde{v}] \\
& +C[\varepsilon, \varepsilon-2(\Delta s+\Delta \widetilde{y}-\Delta \widetilde{v})],
\end{aligned}
$$

where $V$ is the variance operator and $C[.,$.$] denotes the covariance. After uni-$ fication there is no more variability in the exchange rate. Thus (5) simplifies to

$$
\begin{aligned}
V \Delta \widetilde{m}= & V \Delta \widetilde{y}+V[\Delta \widetilde{v}] \\
& -2 C[\Delta \widetilde{y}, \Delta \widetilde{v}] \\
& +C[\varepsilon, \varepsilon-2(\Delta \widetilde{y}-\Delta \widetilde{v})] .
\end{aligned}
$$

Quite likely a further reduction in $V \Delta \widetilde{m}$ as displayed in (6) will occur thanks to monetary union. In sofar the velocity differential is related to the short term interest rate differential, this part of the variance decomposition drops out as well, since there will be a single money market interest rate after unification. Moreover, it is to be expected that business cycles will be more coherent after unification, thus reducing the pre-union $V \Delta \widetilde{y}$, and reducing $\Delta \widetilde{v}$ even further insofar velocity also depends on income.

The convergence observed in Table (3) and predicted for the union at large is now explained in terms of the variables in equation (4). In Table (4), all time-series are indices of each variable vis à vis Germany. Table (4) shows the cross-sectional variances and covariances of these indices in 1995, both for a large cross-section of European countries (EUR11) and for a small core group (EUR4). Clearly the large variation in money for EUR11 is matched by a similar sizable variation in the exchange rate. Since the latter variation is no longer present inside EMU, there will be much less room for divergent monetary trends in the EMU area. For the EUR11 group what remains of the gap between $V\left[M / M_{G E}\right]$ and $V[S]$ is mainly accounted for by the quite sizeable (co)variances involving $\varepsilon$, cf. equation (5). But nevertheless, this effect is not larger than $15 \%$. So that for the EUR11 group the variances for money and the exchange rate dwarf all other (co)variances. As a result, we predict a tremendous increase in similarity between $\Delta m$ and 
Table 4: Results from the Monetary Exchange Rate Model

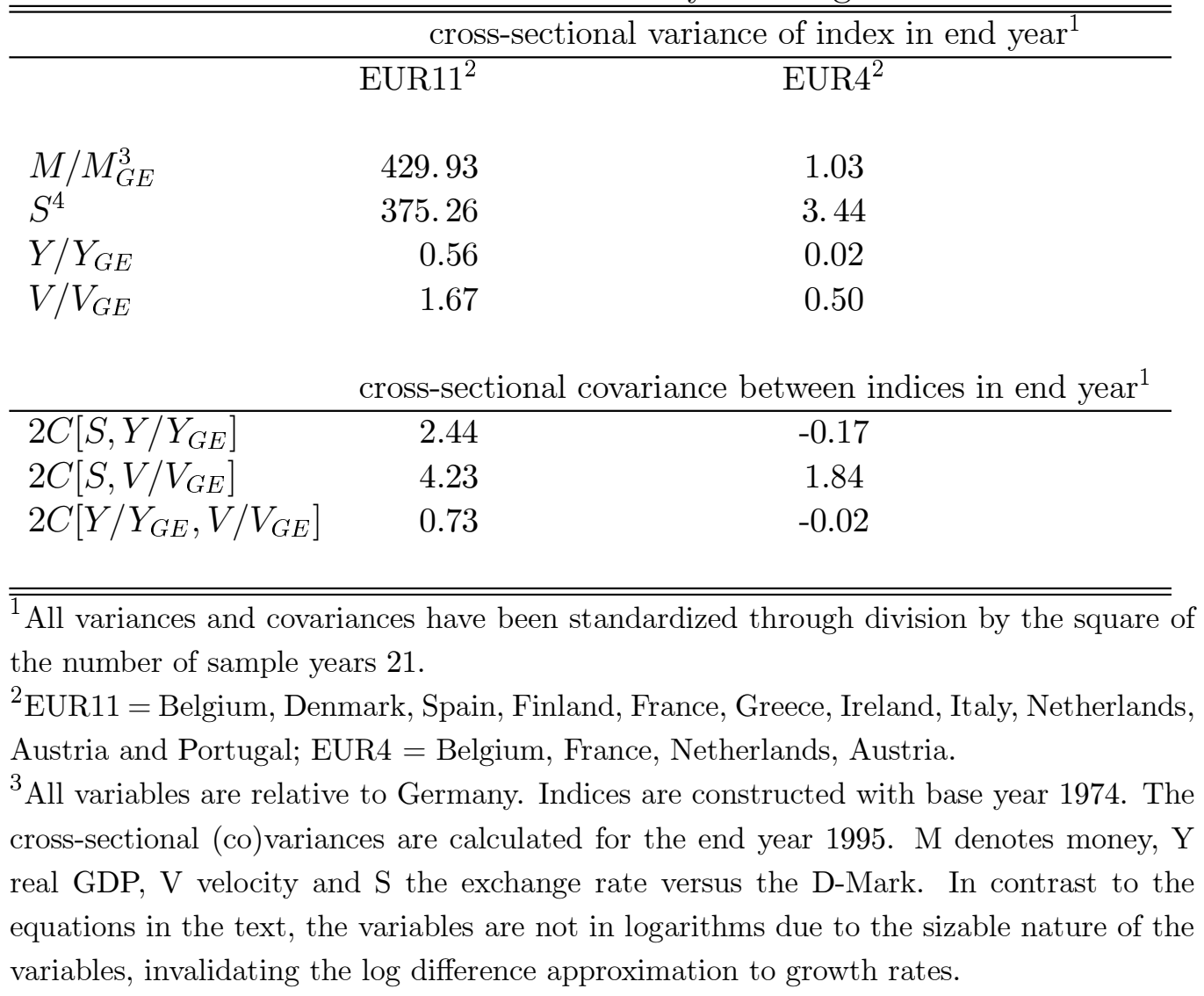


$\Delta m^{*}$ once the variabilty in $\Delta s$ is gone. The data also confirm that for the core group the de facto monetary unification has progressed much further over the years than for the larger group. Evidently, approximately fixed exchange rates already significantly curtail differences in money growth rates. The introduction of a single currency will therefore induce a coherence among the euro-denominated monetary aggregates inside EMU countries similar to what we currently observe inside the United States and Germany, see Table (3). This also implies that the transmission of monetary policy actions through the money markets will be rather uniform right from the start of the union, since both supply and demand will react homogeneously across the union.

Coming back to the first part of our paper, we note that money market developments are, of course, not detached from what happens in the capital markets and further down in the goods and labor markets. Increased money market coherence will at least feed through to other financial markets. Thus the synchronisation of the starting point of the chain of asset substitution will also increase the coherence of subsequent portfolio adjustments. In this way the endogenous response of money markets to EMU reinforces the endogenous response of capital markets. Together, they will work to eliminate differential responses in the transmission of monetary impulses emanating from Frankfurt.

\section{Conclusion}

As of today, European capital and money markets still differ considerably across the EMU countries. If unaffected by monetary unification, these differences may interfere with the uniform transmission of monetary policy. Several papers have voiced concern over this possibility. In contrast to most studies in the area, our paper argues that many differences in the financial structure of the EMU member economies are endogenous to the monetary policy regime in place. For this reason, we feel one cannot extrapolate on the basis of existing structures to form predictions about the transmission after monetary unification. In this paper we try to take into account how the financial market structure will be affected by the regime change. Specifically, we argued that the differences in the capital market structures are strongly correlated with past inflation and inflation uncertainty. Since the EURO regime imposes a unified monetary policy, giving rise to very similar inflation rates across member states, we therefore predict that these differences will wither. 
The forward looking nature of capital markets is already bringing this integration about. But since capital markets have not been fully liberalized, think of remaining differences in the regulation of financial institutions, the ECB might want to put its weight behind efforts to eliminate the remaining barriers to competion completely. In the money markets supply and demand will be harmonized due to the irrevocable fixing of the exchange rates, the single money market rate and the uniform reserve requirement. Hence, our conclusion that differential responses in the transmission of monetary policy actions will soon be a relic of the past.

Some rhetoric from Frankfurt has suggested that the ECB would be very pleased with the level of money demand stability which the current empirical literature on European-wide money demand holds out to her. At the same time, presumably, the ECB prefers its monetary policy actions to have an impact on the European economy unhindered by local money market conditions and differences in the monetary transmission mechanism. Our arguments suggest that the ECB cannot have it both ways effortless. Complete money market integration and the convergence of the monetary transmission mechanisms will come about as a by-product of the unitary inflation regime. But the stability has to be earned the hard way by choosing the proper monetary policy stance over a longer period of time.

With this being realized one might construe a prediction for future monetary policy transmission in the union from a calibration of the past behavior of a single country, rather than using an amalgam of all countries. The idea is that the past behavior of a single country represents a particular scenario and policy stance of the ECB, and hence represents a capital and money market structure that is specific for the particular regime. In this way analogy with the past may work as a predictor for the future.

The paper contains a rather positive note for the ECB. Doomsday messages based on differential transmission creating tension within the union have no bite, since we predict that such differences will be of minor importance. There are other issues, however, which may prove to be bigger obstacles. The literature has exposed the problems that may arise due to the democratic deficit, the strong regional representation in the ECB board, the weakness in safeguards for proper implementation of the stability pact, the interference in monetary policy matters through exchange rate arrangements, the decentralized oversight of financial institutions and the absence of a clearly articulated lender of last resort role. It is a long list which merits proper attention from academics and practioners alike. These issues pertain 
to the survival of the system. The rather transitory issue of transmission differentials, though, we consider to be a non-issue that can be savely ignored from day one of the EURO.

\section{References}

Arnold, I.J.M. (1994), The Myth of a Stable European Money Demand, Open Economies Review, 5, 3, 245-259.

Arnold, I.J.M. and R.G.J. den Hertog (1995), European Time Series Relationships between Inflation and Inflation Uncertainty: In Search of Threshold Levels, De Economist, 143, 4, 495-519.

Arnold, I.J.M. (1997), Monetary Targeting in the EMU: Lessons from the United States, Kredit und Kapital, 30, 3, 348-368.

Arnold, I.J.M. and C.G. de Vries (1998), The Euro, Prudent Coherence?, Tinbergen Institute discussion paper, 98-070/2.

Artis, M.J. (1996), Currency Substitution in European Financial Markets, in The Macroeconomics of International Currencies, Theory, Policy and Evidence, P. Mizen and E. Pentecost, eds, Edward Elgar, 139154.

Artis, M.J., R.C. Bladen-Hovell, and W. Zhang (1992), A European Money Demand Function, in Policy Issues in the Operation of Currency Unions, P. Masson and M. Taylor, eds, Cambridge University Press.

Artis, M.J., Z.G. Kontomelis and D.R. Osborn (1997), Business Cycles for G7 and European Countries, Journal of Business, 70, 2, 249-279.

Artis, M.J., and W. Zhang (1992), International Business Cycles and the ERM: is there a European business cycle?, CEPR discussion paper no. 1191.

Backus, D., S. Foresi, C. Telmer (1996), Affine Models of Currency Pricing, NBER working paper 5623.

Ball, L. (1992), Why Does High Inflation Raise Inflation Uncertainty?, Journal of Monetary Economics, 29, 371-388. 
Barclay, M.J. and C.W. Smith (1995), The Maturity Structure of Corporate Debt, Journal of Finance, 609-631.

Barnea, A., R.A. Haugen and L.W. Senbet (1980), A Rationale for Debt Maturity Structure and Call Provisions in the Agency Theoretic Framework, Journal of Finance, 1223-1234.

Bekx, P. and G. Tullio (1989), A Note on the European Monetary System, and the Determination of the DM-Dollar Exchange Rate, Cahiers Economiques de Bruxelles, 123, 329-343.

Bernanke, B. S., and M. Woodford (1997), Inflation Forecasts and Monetary Policy, Journal of Money, Credit and Banking 29, 653-684.

Bester, H. (1985), Screening versus Rationing in Credit Markets with Imperfect Information, American Economic Review, 850-855.

Borio, C.E.V. (1996), Credit Characteristics and the Monetary Policy Transmission Mechanism in Fourteen Industrial Countries: Facts, Conjectures and Some Econometric Evidence, in Monetary Policy in a Converging Europe, K. Alders, K.Koedijk, C.Kool and C. Winder, eds, Kluwer, 77-115.

Browne, F.X., G. Fagan and J. Henry (1997), Money Demand in EU Countries: A Survey, European Monetary Institute Staff Paper 7.

Britton, E. and J. Whitley (1997), Comparing the Monetary Transmission Mechanism in France, Germany and the United Kingdom: Some Issues and Results, Bank of England Quarterly Bulletin, 152-162.

Bundesbank (1995), Demand for Money and Currency Substitution in Europe, Deutsche Bundesbank Monthly Report, January, 33-49.

Cassard, M., T. Lane and P. Masson (1994), ERM Money Supplies and the Transition to EMU, IMF Working Paper, 94/1.

Calvo, G.A, and M. Obstfeld (1990), Time Consistency of Fiscal and Monetary Policy: A comment, Econometrica, 1245-1247.

Campbell, J.Y. and R.J. Shiller (1996), A Scorecard for Indexed Government Debt (1996), in NBER Macroeconomics Annual MIT Press, Cambridge, 155-197. 
Carlino, G.A. and R. DeFina (1997), The Differential Effects of Monetary Policy: Evidence from the U.S. States, FED working paper 97-12.

Carlino, G. A. and R. DeFina (1998), Monetary Policy and the U.S. States and Regions: Some Implications for European Monetary Union, FED working paper 98-17.

Cukierman, A. (1992), Central Bank Strategy, Credibility, and Independence: Theory and Evidence, MIT press.

Cukierman, A. and A Meltzer (1986), A Theory of Ambiguity, Credibility, and Inflation under Discretion and Asymmetric Information, Econometrica, 54, 1099-1128.

De Grauwe, P. (1996), Inflation Convergence during the Transition to EMU, in Inflation and Wage behavior in Europe, P. De Grauwe, S. Miscosi and G. Tullio, eds., Clarendon Press, 193-208.

Dornbusch, R., C.A. Favero and F. Giavazzi (1998), A Red Letter Day?, CEPR working paper 1804.

Eijffinger S.C.W. and J. De Haan (1996), The Political Economy of Central Bank Independence, Special Papers in International Economics, 19, Princeton University.

Eijffinger, S.C.W., E. Schaling and M. Hoeberichts (1998), Central Bank Independence: A Sensitivity Analysis, European Journal of Political Economy, 73-88.

European Monetary Institute (1998), Convergence Report, EMI, Frankfurt, March.

Fagan G. and J. Henry (1998), Long Run Money Demand in the EU: Evidence for Area-wide Aggregates, Empirical Economics, 23, 483-506.

Fase, M.M.G. and C.C.A. Winder (1994), Money Demand within EMU - an Analysis with the Divisia Measure, De Nederlandse Bank Quarterly Bulletin, september, 25-55.

Fase, M.M.G. and C.C.A. Winder (1997), Wealth and the Demand for Money in the European Union, De Nederlandse Bank Staff Reports, 6. 
Fatas, A. (1997), EMU: Countries or Regions? Lessons from the EMS Experience, European Economic Review, 41, 3-5, 743-751.

Friedman, M. (1977), Nobel Lecture: Inflation and Unemployment, Journal of Political Economy, 85, 451-472.

Giannini, C. and C. Monticelli (1997), Which TARGET for Monetary Policy in Stage Three? Issues in the Shaping of the European Payment System, Weltwirtschaftliches Archiv, 133, 657-682.

Giovannetti, G. and R. Marimon (1998), An EMU with Different Transmission Mechanisms?, paper presented at the ZEI conference.

Grier, K.B., and M.J. Perry (1998), On Inflation and Uncertainty in the G7 countries, Journal of International Money and Finance, 17, 671-689

Groeneveld, J.M. (1998), Inflation Patterns and Monetary Policy, Lessons for the European Central Bank, Edward Elgar.

Gros, D. and N. Thygesen (1998), European Monetary Integration, Longman Harlow.

Hayo, B., and B. Uhlenbrock (1998), Sectoral Effects of Monetary Policy in Germany, paper presented at the ZEI conference.

Hughes Hallett, A.J. and T. Warmedinger (1998), On the Asymmetric Impacts of a Common Monetary Policy, paper presented at the ZEI conference.

Kashyap, A.K., and J.C. Stein (1997), The Role of Banks in Monetary Policy: A Survey with Implications for the European Monetary Union, Economic Perspectives Federal Reserve Bank of Chicago, 2-18.

Kneeshaw, J.T. (1995), A Survey of Non-financial Sector Balance Sheets in Industrialised Countries: Implications for the Monetary Policy Transmission Mechanism, BIS working paper 25.

Kremers, J.J.M. and T.D. Lane (1990), Economic and Monetary Integration and the Aggregate Demand for Money in the EMS, IMF Staff Papers 37, 777-805. 
Krugman, P. (1993), Lessons of Massachusetts for EMU, in Adjustment and Growth in the European Monetary Union, Torres and Giavazzi, eds, Cambridge University Press.

Läufer, N.K.A. (1992), A Monetary Policy for Unified Germany: Europeanization of money supply targeting, in European integration in the world economy, H.-J. Vosgerau, ed., Springer-Verlag, Berlin, 46-70.

La Cour, L. and R. MacDonald (1997), Modelling the ECU against the US Dollar: A Structural Monetary Interpretation, Discussion Paper, no. 2, Centre for Financial Markets Research, University of Strathclyde.

Lemmen, J. (1998), Managing government default risk, mimeo Financial Markets Group, London School of Economics.

Magill, M. and M. Quinzii (1996), Theory of Incomplete Markets, MIT Press, Cambridge.

Modigliani, F. and M. Miller (1958), The cost of capital, corporation finance, and the theory of investment, American Economic Review 48, 261-297.

Minford, P. and E. Nowell (1998), Nominal Contracts as Behaviour towards Risk, paper presented at the 1997 Konstanz Seminar on Monetary Policy.

Missale, A. and O.J. Blanchard (1994), The Debt Burden and Debt Maturity, American Economic Review, 309-319.

Monticelli, C. and M-O. Strauss-Kahn (1993), European Integration and the Demand for Broad Money, The Manchester School of Economic and Social Studies, 61, 345-366.

Monticelli, C. (1996), EU-wide money and cross-border holdings, Weltwirtschaftliches Archiv, 132, 215-235.

Persson, M., T. Persson, and L.E.O. Svensson (1987), Time Consistency of Fiscal and Monetary Policy, Econometrica, 1419-1432.

Rother, P.C. (1998), European Monetary Integration and the Demand for Money, Journal of International Money and Finance, 17, 691-711. 
Spencer, P. (1997), Monetary Integration and Currency Substitution in the EMS: The Case for a European Monetary Aggregate, European Economic Review, 41, 1403-1419.

Stiglitz, J. and A.M. Weiss (1981), Credit Rationing in Markets with Imperfect Information, American Economic Review, 393-410.

Svensson, L.E.O. (1997), Inflation forecast targeting: Implementing and monitoring inflation targets, European Economic Review 41, 11111146 .

Tullio, G., E. De Souza, and P. Giucca (1996), The Demand for Money Functions in Europe and in Germany before and after the Fall of the Berlin Wall, in Inflation and Wage behavior in Europe, P. De Grauwe, S. Miscosi and G. Tullio, eds., Clarendon Press, 310-337.

Wesche, K. (1997), The Demand for Divisia Money in a Core Monetary Union, Federal Reserve Bank of St. Louis Review, 79, 5, 51-60. 